\title{
Harmonisation of higher education in Africa: 20 years after the Bologna Process
}

\author{
Abebaw Yirga Adamu* \\ doi: http://dx.doi.org/10.18543/tjhe-9(1)-2021pp103-126
}

Received: 18 October 2020

Accepted: 9 September 2021

\begin{abstract}
It has been 20 years since the Bologna Process has been realized, and the present paper examines efforts made to harmonise higher education in Africa. Similar to other continents, the higher education reform in Africa is inspired by the Bologna Process. This is clearly reflected in the African Union strategy for harmonisation of higher education and different reforms and harmonisation initiatives. The reforms in African higher education are directly and indirectly influenced by the European Union which is also the main financer and technical partner in the development and implementation of higher education harmonisation in Africa. There are different factors that affect the institutionalisation and sustainability of harmonisation initiatives in Africa. Some of the major factors include lack of strong and genuine cooperation among African HEIs, lack of nations' political commitment to higher reforms, and lack of contextualisation in adopting reforms and strategies. Although the effort to harmonise African higher education is commendable, it is important to look for innovative strategies and reforms which are mainly based on the actual challenges that Africa is facing and the ultimate goal it envisions to achieve. Africa also needs to earnestly 'conainise' (continentalise, nationalise and institutionalise) reforms and harmonisation strategies adopted from elsewhere.
\end{abstract}

Keywords: Africa; African Union; Bologna process; Europe; European Union; harmonisation; higher education.

\section{Introduction}

Globalisation is a phenomenon that requires increased competition, interdependence and interconnectedness, and this is mainly based on

\footnotetext{
*Abebaw Yirga Adamu (abebawy2001@gmail.com; abebaw.yirga@aau.edu.et), PhD in Education, is an Associate Professor at the Department of Educational Planning and Management, Addis Ababa University, Ethiopia.

More information about the author is available at the end of this article.
} 
innovation and information which are knowledge intensive, ${ }^{1}$ and has a lot to do with higher education. It is argued that "higher education both drives, and is driven by, globalisation." ${ }^{2}$ Higher education drives globalisation through the training of a highly trained workforce that contributes to innovation and research. It is also driven by globalisation as its policies and reforms are often informed and imposed by the process of globalisation. ${ }^{3}$

Internationalisation is another phenomenon that has impacted higher education. It is considered as "both a response to, and a contributing factor facilitating, globalisation." ${ }^{4}$ The global higher education sector has been responding to the quest for everlasting improvement, competition and challenges of globalisation and internationalisation through different strategies. One of these strategies is harmonisation of higher education, which is "a process of ensuring articulation, both horizontal and vertical, between programs and institutions among various higher education systems." Harmonisation also implies "the agreement, synchronization and coordination of education systems to strategically develop and strengthen the capacity of HE institutions to respond simultaneously to the educational and employability needs of populations." 6

Although there are different types and initiatives of harmonisation that have been taking place across the global higher education landscape, one could argue that the Bologna Process, which is a European concerted response to major challenges facing their higher education, ${ }^{7}$ is the largest and

1 Martin Carnoy, "Globalisation, Educational trends and the Open Society," Open Society Institute, Education Conference - Education and open society: A critical look at new perspectives and demands, 2005, https://www .opensocietyfoundations.org/uploads/7fab0f354f84-4ed7-82d6-ee2346b7c142/carnoy_english.pdf.

2 OECD, "Executive Summary," in Higher Education to 2030, Volume 2, Globalisation, ed. Center for educational Research and Innovation (Paris: OECD, 2009), 13-16. https://doi. org/10.1787/9789264075375-en.

3 Abebaw Y. Adamu. "Internationalization of higher education in Africa: Introducing credit accumulation and transfer system," International Journal of Public Policy 8, no.4/5/6 (2012): 199-213. https://doi.org/10.1504/IJPP.2012.048713.

${ }^{4}$ Douglas E. Mitchell and Selin Yildiz Nielsen. "Internationalisation and Globalisation in Higher Education," in Globalisation, Education and Management, ed. Hector Cuadra-Montiel (London:IntechOpen, 2012), 3-22. DOI: 10.5772/48702.

5 Emnet T. Woldegiorgis, "Conceptualizing Harmonization of Higher Education Systems: The Application of Regional Integration Theories on Higher Education Studies," Higher Education Studies 3, no. 2 (2013): 12-23.

${ }^{6}$ Association for the Development of Education in Africa, "Policy Brief: Harmonization of Higher Education in Africa or Why We Need to Hang in There Together," 2015, http://www. adeanet.org/en/system/files/policy_brief_harmonization_en.pdf.

${ }^{7}$ Ingrid Lunt, "The implementation of the BP for the development of a European qualification in psychology," European Psychologist 10, no. 2 (2005): 86-92. https://doi. org/10.1027/1016-9040.10.4.350. 
the best example for continental level harmonisation of higher education..$^{8,910}$ The harmonisation of higher education systems in Europe was first initiated in 1998 in Sorbonne, France by the ministers responsible for higher education from four European countries - France, Germany, Italy and the United Kingdom. In the meeting, the ministers discussed and signed a joint declaration on the "harmonisation of the architecture of the European higher education system." 11 The Sorbonne Declaration is aimed mainly at creating a European Higher Education Area (EHEA) through developing various mechanisms that facilitate student mobility, common degree structure and mutual recognition of studies and degrees. The Declaration is perceived as predecessor of the Bologna Process which was launched in 1999 by 29 signatories of the Bologna Declaration.

The Bologna Process is considered as the most comprehensive higher education reform in the world in the last several decades. ${ }^{12,13,14}$ At the outset, it aims at promoting greater compatibility and comparability of the European higher education system..$^{15}$ In the last two decades, the Bologna Process has integrated different objectives,${ }^{16}$ including enhancing Europe's scientific

${ }^{8}$ Roger J. Chao, "Reflections on the Bologna Process: the making of an Asia Pacific Higher Education Area," European Journal of Higher Education 1, no.2-3 (2011): 102-118. https://doi.org/10.1080/21568235.2011.629040.

9 Jane Knight, "A model for the regionalization of higher education: The role and contribution of tuning," Tuning Journal for Higher education 1, no. 1 (2013): 105-125. http:// doi.org/10.18543/tjhe.

${ }_{10}$ Ayenachew. A. Woldegiyorgis, "Harmonisation of Higher Education in Africa and Europe: Policy Convergence at Supranational Level," Tuning Journal for Higher Education 5, no. 2 (2018): 133-157. http://dx.doi.org/10.18543/tjhe-5(2)-2018

${ }^{11}$ Sorbonne Declaration, "Joint declaration on harmonisation of the architecture of the European higher education system,” 1998, http://www.ehea.info/media.ehea.info/file/1998_ Sorbonne/61/2/1998_Sorbonne_Declaration_English_552612.pdf

${ }_{12}$ European Commission, "Towards the European Higher Education Area by 2025," 2018, https://ec.europa.eu/commission/news/towards-european-education-area-2025-2018may-22_en.

13 Tobias Brandle, "Only a Matter of Education Policy Ideals? German Professors' Perception of the Bologna Process," Higher Education Quarterly 70, no. 4 (2016): 354-383. https://doi.org/10.1111/hequ.12095.

${ }^{14}$ Barbara M. Kehm, "The Future of the Bologna Process -The Bologna Process of the future," European Journal of Education 45, no. 4 (2010): 529-534. https://doi.org/10.1111/ j.1465-3435.2010.01453.x.

15 Bologna Declaration, "Joint Declaration of the European Ministers of Education," 1999, https://www.eurashe.eu/library/bologna_1999_bologna-declaration-pdf/.

${ }^{16}$ Hannah Moscovitz and Hila Zahavi, "The Bologna Process as a Foreign Policy Endeavour: Motivations and Reactions to the Externalisation of European Higher Education," European Journal of Higher Education 9, no. 1 (2019): 7-22 https://doi.org/10.1080/21568235.2018.1561316. 
capacity, the modernisation, competitiveness and attractiveness of the European higher education, ${ }^{17,18,19}$ and facilitation of comparability and recognition of studies and qualifications. Implementation reports indicate that the Bologna Process has achieved most of the goals for European higher education set two decades ago.$^{20}$ However, this does not necessarily mean that every plan has been fully achieved. ${ }^{21}$ There are criticisms and dissatisfaction among higher education institutions (HEIs) in different countries regarding its ambition, objectives and implementation strategies..$^{22,23,24}$ The 2018 Bologna Process implementation report also indicates that the implementation varies across the 48 signatory countries and there are some gaps that need to be addressed. ${ }^{25}$

Based on stable foundations provided through the Bologna Process, the European Commission is now planning to develop a new initiative which is referred to as "Towards the European Higher Education Area by 2025". This initiative aims to improve academic mobility and educational opportunities in the European Union (EU), empower the youth, and "intensify cooperation in areas such as multilingualism, innovation and mutual recognition of diplomas, and also to provide inspiration to non-EU countries to follow." 26

${ }^{17}$ Manja Klemenčič, "20 Years of the Bologna Process in a Global Setting: The external dimension of the Bologna Process revisited," European Journal of Higher Education 9, no.1 (2019): 2-6. https://doi.org/10.1080/21568235.2019.1570670.

${ }_{18}$ Bergen Communiqué, "European Higher Education Area - Achieving the Goals". Communique of the Conference of European Ministers Responsible for Higher Education, Bergen, 19-20 May 2005, http://ehea.info/media.ehea.info/file/20050412-13_Mondorf/67/6/ BFUG5_8_Draft_579676.pdf.

${ }^{19}$ London Communiqué, "European Higher Education in a Global Setting: A strategy for the External Dimension of the Bologna Process," London, 17-18 May 2007, http://www.ehea. info/media.ehea.info/file/EHEA_in_a_Global_Context/24/2/Strategy_plus_possible_ actions_597242.pdf.

${ }^{20}$ Don F.Westerheijden et al., The First Decade of Working on the European Higher Education Area: The Bologna Process Independent Assessment: Executive Summary, Overview and Conclusions (Ghent: University of Ghent, 2010).

${ }^{21}$ David Matthews, "Bologna Process Still 'Treading Water', Say Critics". The World University Ranking, May 29, 2018, https://www.timeshighereducation.com/news/bolognaprocess-still-treading-water-say-critics.

${ }^{22}$ Brandle, "Only a Matter of Education Policy Ideals?".

${ }^{23}$ Hans Pechar, "The Decline of an Academic Oligarchy: The Bologna Process and 'Humboldt's Last Warriors," in European Higher Education at the Crossroads: Between the Bologna Process and National Reforms, ed. Adrian Curaj, Peter Scott, Lazar Vlasceanu, and Lesley Wilson (Dordrecht: Springer, 2012), 613-630.

${ }^{24} \mathrm{Kehm}$. "The future of the Bologna Process".

${ }^{25}$ European Commission/EACEA/Eurydice, The European Higher Education Area in 2018: Bologna Process Implementation Report" (Luxembourg: Publications Office of the European Union, 2018).

${ }^{26}$ European Commission/EACEA/Eurydice, The European Higher Education Area, 4. 
Although the Bologna Process has been mainly established to address the common European higher education problems, it has clear impacts on the reforms and harmonisation of higher education worldwide,,$^{27,28,29,30}$ and has become frame of reference in the harmonisation of higher education. ${ }^{31}$ Despite a study claiming that "for the moment, the Bologna model's transfer is not a success," 32 it is becoming more and more evident that African higher education policy makers prefer and tend to rely on 'adapting' the Bologna Process in the harmonisation of higher education in Africa.

It has been 20 years since the Bologna Process has been realized, and the present paper examines efforts made to harmonise African higher education which is inspired and significantly influenced by the Bologna Process. Accordingly, the paper present and discuss the following three sections (i) frameworks for harmonisation of higher education in Africa, (ii) strategies and tools introduced to enhance harmonisation of higher education in Africa, and (iii) EU's influence on the higher education reform in Africa, and (iv) factors affecting the implementation and institutionalisation of harmonisation of higher education in Africa.

\section{Frameworks for harmonisation of higher education in Africa}

Beside the impact of globalisation and internationalisation, underfunding and different higher education systems in Africa are also challenging the sector. ${ }^{33}$ Since the early 1980s, Africa has been striving to address these challenges through developing and implementing different policies and strategies including the frameworks for harmonisation of higher education in Africa. In the African context, harmonisation is considered as "an instrument for enabling African higher education to contribute to and be aligned with the

27 David Crosier and Teodora Parveva, The Bologna Process: Its Impact on Higher Education Development in Europe and Beyond (Paris: UNESCO, 2013).

${ }^{28}$ Emnet T. Woldegiorgis, Petronella Jonck, and Anne Goujon, "Regional Higher Education Reform Initiatives in Africa: A Comparative Analysis with the Bologna Process," International Journal of Higher Education 4, no.1 (2015): 241-253. https://doi.org/10.5430/ijhe.v4n1p241.

${ }^{29}$ Pavel Zgaga, Looking Out: The Bologna Process in a Global Setting. On the "External Dimension” of the Bologna Process (Oslo: Norwegian Ministry of Education and Research, 2006).

${ }^{30}$ Aristotelis Zmas, "Global Impacts of the Bologna Process: International Perspectives, Local Particularities," Compare: A Journal of Comparative and International Education 45, no. 5 (2015): 727-747. https://doi.org/10.1080/03057925.2014.899725.

${ }^{31}$ Chao, "Reflections on the Bologna Process", 1.

32 Jean-Emile Charlier and Sarah Croche, "Can the Bologna Process Make the Move Faster towards the Development of an International Space for Higher Education Where Africa Would Find Its Place?", Journal of Higher Education in Africa 7, no. 1\&2 (2009): 39-59.

33 Adamu, "Internationalization of higher education in Africa", 209. 
African vision of integration. ${ }^{34}$ The African Union (AU) clearly indicates that "harmonization is not synonymous with standardization, creating uniformity, or achieving identical higher education systems. [It is rather] the agreement, synchronization, and coordination of higher education provision in Africa." ${ }^{35}$

As clearly indicated in the policy brief of the Association for the Development of Education in Africa harmonisation is a top priority for Africa. ${ }^{36}$ The Arusha Convention, which was adopted in 1981, could probably be the first framework developed to harmonise higher education in Africa. This Convention is one of the five regional conventions initiated by UNESCO to promote international cooperation in higher education through facilitating academic mobility and recognition of studies and degrees. ${ }^{37,38}$ The other regional conventions include, the convention in Latin America and the Caribbean- 1974 revised in 2019, the Arab States-1978 revised in 2018, Europe- 1979 revised in 2009, and Asia and the Pacific-1983 revised in 2011.

Three decades after its ratification, the Arusha Convention had only about 20 signatory African countries. This indicates that the Convention did not attract as many countries as possible, bring the intended changes and live up to its expectation. ${ }^{39}$ While many African countries were not clear on the need of ratifying the Arusha Convention, ${ }^{40}$ Europe effectively used its regional convention and advanced on the harmonisation of higher education which ultimately becomes the benchmark for higher education reform, as well as an inspiration for cross-regional cooperation in higher education worldwide including Africa, Asia and Latin America. ${ }^{41,42}$

${ }^{34}$ African Union Commission and European Commission, "Preface", in Tuning and Harmonisation of Higher Education: The African Experience, ed. Carles Awono Onana, et al. (Bilabo: University of Deusto, 2014), 9-10.

${ }^{35}$ Sarah Hoosen, Neil Butcher, and Betarice K. Njenga, "Harmonisation of Higher Education Programmes: A strategy for the African Union". African Integration and Development Review 3, no. 1 (2009): 1-36.

36 Association for the Development of Education in Africa, "Policy brief", 1.

${ }^{37}$ UNESCO, Higher Education in a Globalized Society: UNESCO Education Position Paper (Paris: UNESCO, 2004).

${ }^{38}$ UNESCO, Evaluation of UNESCO's Regional Conventions on the Recognition of Qualifications in Higher Education (Paris: UNESCO, 2016).

39 Adamu, "Internationalization of higher education in Africa", 204.

${ }^{40}$ Olusola Oyewole, "African Harmonisation: An Academic Process for a Political End?" Chronicle of African Higher Education, 2013, http://www.inhea.org/wp-content/ uploads/2016/02/Oyewole-Harmonisation.pdf.

${ }^{41}$ Christian Tauch. "The Bologna Process: State of Implementation and External Dimension," in Opening up to the Wider World: The External Dimension of the Bologna Process, ed. Franziska Muche (Bonn: Lemmens Verlags- and Mediengesellschaft mbH, 2005) 23-30.

${ }^{42}$ Chao, "Reflections on the Bologna Process", 2. 
The Continental Education Strategy for Africa (CESA 2016-2025) is another framework that facilitates harmonisation of higher education in Africa. CESA aims to come up with a strategy that demands a paradigm shift in the organisation and provision of education and training in Africa, and harmonisation is one of its guiding principles and strategic objectives.

The Plan of Action for the Second Decade of Education for Africa (2006-2015) also aims to strengthen HEIs' capacity through developing and implementing innovative approaches to intra-African collaboration and harmonisation, improving quality of higher education and promoting academic mobility across the continent. ${ }^{43}$ Harmonising the diverse systems of higher education in Africa is also an important aspect of the regional integration objective of the continent. To realize this plan and significantly contribute to the development of higher education in Africa, the AU came up with a strategy referred to as 'The African Union Strategy for Harmonisation of African Higher Education Programmes' ${ }^{44}$ The strategy mainly aims to passage the gap in the education systems, promote joint curriculum development initiatives and quality assurance mechanisms, facilitate academic mobility and recognition of qualifications, and enhance continental integration in different aspects. The strategy has also identified different result areas that indicate AU's strategic approach to address the structural and technical challenges faced in ratifying and implementing the Arusha Convention.

The AU strategy for harmonisation, which has taken lessons from similar initiatives, specifically focuses on fostering joint cooperation in information exchange, comparability of qualifications, and standardisation of curricula. ${ }^{45,46}$ It is believed that effective implementation of this strategy significantly contributes to strengthening African Higher Education and Research Space (AHERS) which aims to promote intra-Africa academic mobility, enhance quality assurance and promote the establishment of joint degree programmes at continental level. ${ }^{47}$ The AHERS, which is significantly influenced by and

${ }^{43}$ African Union, "Second Decade of Education for Africa (2006-2015): Plan of Action," 2006, http://www.unesco.org/new/fileadmin/MULTIMEDIA/FIELD/Dakar/pdf/AU\%20 SECOND\%20DECADE\%20ON\%20EDUCTAION\%202006-2015.pdf.

${ }^{44}$ African Union, Harmonization of Higher Education Programmes in Africa: A Strategy for the African Union (Addis Ababa: African union, 2007).

${ }^{45}$ Hoosen, Butcher, and Njenga, "Harmonisation of higher education programmes", 16.

${ }^{46}$ African Union, "Harmonization of higher education".

47 UNESCO, "The New Dynamics of Higher Education and Research for Societal Change and Development," World Conference on Higher Education, Communiqué, July 5-8, 2009, Paris: UNESCO. 
in many ways similar to EHEA, is supported by the European Commission through its Pan-African programme which in turn provides support to the Africa-EU strategic partnership.

The harmonisation of higher education and the establishment of AHERS have sought to stimulate greater collaboration in research and other missions of higher education in Africa. It also aimed at increasing the continent's share in knowledge creation and research production through enhancing its research capacity and academic standards The AU strategy for harmonisation of higher education also necessitated the revision of the Arusha Convention and this was adopted on 12 December 2014 in Addis Ababa, Ethiopia. One of the aims of the revised Convention (commonly referred to as the Addis Convention) is contributing to the harmonisation of qualifications by addressing limitations observed in the Arusha Convention and taking into account current global trends. ${ }^{48}$

The "Agenda 2063-The Africa We Want", which was adopted 2013 by the African Union Commission (AUC), is also a good framework that facilitated harmonisation of higher education in the continent, inter alia, through fostering harmonisation of educational standards and qualifications; establishing a continental accreditation agency that promotes academic and student mobility; and strengthening the Pan African University.

Within these frameworks, several continental strategies and tools have been introduced to augment the harmonisation of higher education in Africa.

\section{Strategies for harmonisation of higher education in Africa}

HEIs are expected to play a key role in the global knowledge production and address national and continental priorities while operating in a global context which requires internationalisation of the higher education system. However, the higher education system in Africa is considered as "probably the most internationalized higher education system in the world-not by participation but by omission." ${ }^{49}$ Although this is a challenge by itself, the African Union is actively engaged in developing and implementing different continental harmonisation strategies and activities in response to the impacts

${ }^{48}$ UNESCO. "Revised Convention on the Recognition of Studies, Certificates, Diplomas, Degrees and Other Academic Qualifications in Higher Education in African States," 2014, http:// portal.unesco.org/en/ev.php-URL_ID=49282\&URL_DO=DO_TOPIC\&URL_SECTION=201. html.

49 Damtew Teferra, "The international dimension of higher education in Africa: Status, challenges, and prospects," in Higher Education in Africa: The International Dimension, ed. Damtew Teferra and Jane Knight (Accra: Association of African University, 2008), 44-79. 
of globalisation and internationalisation of higher education. One of the envisioned contributions of harmonisation is facilitating regional integration and inter-institutional partnership. This requires significant commitment of different actors in relation to funding, coordination and institutionalisation of different initiatives which is a challenge encountered by African countries and their HEIs. This lessens the potential contributions of harmonisation to regional integration. However, initiatives that promote academic mobility and joint curriculum development and programme provision have comparative contribution to the inter-institutional partnership in the continent.

As discussed earlier, most of the African higher education harmonisation strategies and tools are developed based on lessons drawn from the Bologna Process, and it is indicated that this is mainly based on the assumption that Africa is facing some similar challenges to that of what Europe has faced before and in the 1990s (e.g. recognition of studies and qualifications, lack of opportunity to study abroad and quality assurance).$^{50}$ However, this does not necessarily mean that all the current challenges facing African higher education are similar to that of what Europe has faced before. This paper focuses on selected harmonisation initiatives and strategies that deal with academic mobility and programme development and implementation, and quality assurance and accreditation.

\section{III.1. Academic mobility and programme development and implementation}

Students, staff and researchers mobility is one of the strategies that contributed to the harmonisation of higher education in the continent. The Intra-Africa Academic Mobility Scheme (including its predecessor - IntraAfrica, Caribbean and Pacific Academic Mobility Scheme), the Mwalimu Nyerere Scholarship Scheme, Tuning Africa and the Pan African University (PAU) are some of the continental initiatives that promote internationalisation and harmonisation of higher education through activities involving mobility, joint curriculum reform and development and teaching-learning improvement.

The Intra-Africa Academic Mobility Scheme aims to strengthen international cooperation and cooperation between HEIs in Africa, and enhance the quality of higher education. In many ways, this is similar to the Erasmus programme which is a European Union initiative that provides opportunities for students to study in different European countries. The

${ }^{50}$ Goolam Mohamedbhai, "Towards an African Higher Education and Research Space (AHERS): Summary Report”, 2013. http://www.adeanet.org/en/system/files/resources/ahers_ summary_report.pdf 
Mwalimu Nyerere Scholarship aims to improve the skills and competences of students and staff, and promote research in the continent. The PAU, which is a continental university network that supports the development of centres of excellence in Africa, also promotes student mobility and research networking within the continent. ${ }^{51}$

Tuning Africa is another continental initiative that promotes academic mobility and programme development implementation. It contributes to quality enhancement mainly through developing joint curriculum and improving teaching-learning which in turn contributes to recognition of qualifications.$^{52} \mathrm{It}$ also contributes to improving the quality of education in the continent through matching graduates' academic qualifications with the skills and competences required in the world of work..$^{53}$ It is part of the Joint Africa-EU Strategy that aims to support the harmonisation of higher education programmes in Africa. Tuning Africa is not unique to Africa, rather it is a replica of other similar continental initiatives -Tuning Europe and Tuning Latin America.

\section{III.2. Quality assurance and accreditation}

Enhancing the quality of higher education is one of the major goals of harmonisation of higher education in Africa and elsewhere. Quality is an important issue that all HEIs are making every effort to ensure. Accordingly, several countries have acknowledged the importance of establishing a national higher education quality assurance (QA) agency. ${ }^{54}$

In a globalized world, quality is not only an issue of a nation, and thus it requires closely working with other similar agencies through establishing subcontinental, continental and international QA agencies and networks. This helps to create collaborations through sharing information, good practices and experiences, ${ }^{55}$ which in turn facilitate mobility of students and staff and recognition of studies and qualification. In Africa, sub-continental QA agencies and networks including the Inter-University Council for East Africa (IUCEA),

51 African Union, "First Progress Report of the Chairperson of the Commission on Academic Mobility Scheme in Africa," 2018, https://au.int/sites/default/files/documents/34072doc-auc.report.academic.mobility. prc_.29.03.pdf

${ }^{52}$ Karola Hahn and Damtew Teferra, "Tuning as Instrument of Systematic Higher Education Reform and Quality Enhancement: The African Experience". Tuning Journal for Higher education 1, no. 1 (2013): 127-163. http://dx.doi.org/10.18543/tjhe-1(1)-2013pp127-163.

53 Oyewole "African harmonisation", 3.

${ }^{54}$ Hahn and Teferra. "Tuning as instrument of systematic higher education reform", 134.

${ }_{55}$ Chiyevo Garwe, E. and Lovemore Gwati, "The role of International and Regional Quality Assurance Bodies”. Higher Education Research 3, no. 1 (2018): 15-22. doi: 10.11648/j. her.20180301.14. 
the Southern African Quality Assurance Network (SAQAN), and the African and Malagasy Council for Higher Education (CAMES) are becoming more active and visible. Most of these agencies and networks had good working relationships with similar agencies, networks and development partners from the global north than their African counterparts. Although these QA bodies have common issues, there has been a lack of strong and active continental QA networks that provide platforms for sharing lessons, information, experiences and practices. The African Quality Assurance Network (AfriQAN), which was established in 2009, aims to fill this gap by serving as a continental network of higher education QA agencies in Africa. ${ }^{56}$ AfriQAN aims to promote harmonised QA standards and create a competitive African higher education space through instilling QA culture in African HEIs and encouraging cooperation and association among QA agencies within Africa. ${ }^{57}$

The AUC recognized that lack of a strong regional body responsible for enhancing access to quality higher education and facilitating mutual recognition of academic qualifications are some of the major challenges that hinder the competitiveness of African higher education in the global arena. These necessitate the establishment of a continental quality assurance and regulatory framework which is referred to as the Pan-African Quality Assurance and Accreditation Framework (PAQAF). PAQAF, which is part of the African strategy for harmonisation of higher education, aims to improve the quality of higher education in the continent. Effective implementation of PAQAF is envisioned through the development and implementation of different tools and action lines including the Addis Convention; African Quality Rating Mechanism (AQRM); and the Harmonisation of African Higher Education Quality Assurance and Accreditation (HAQAA).

AQRM is a continental QA tool developed by the AU mainly to enhance institutional culture of quality ${ }^{58}$ compare performance of similar HEIs,${ }^{59}$ and contribute toward making African HEIs more globally competitive and

56 Juma Shabani, Peter Okebukola, Olusola Oyewole, "Quality Assurance in Africa: Towards a Continental Higher Education and Research Space". International Journal of African Higher Education 1, no. 1 (2014): 139-171.

${ }^{57}$ Garwe and Gwati, "The role of international and regional quality assurance bodies", 16-17.

${ }^{58}$ African Union, "African Quality Rating Mechanism (AQRM) Survey Questionnaire. Revised Version," 2013, https://au.int/sites/default/files/newsevents/working documents/27609-wd-aqrm_q_english_august_2013.pdf.

${ }^{59}$ Lazarus Nabaho and Wilberforce Turyasingura, "An exploration of the 'African (Union Commission's) perspective' of quality and quality assurance in higher education: Latent voices in the African Quality Rating Mechanism (AQRM)," Tuning Journal for Higher Education 6, no.2 (2019): 73-95. http://dx.doi.org/10.18543/tjhe-6(2)-2019pp73-95. 
locally relevant. ${ }^{60}$ It aimed to achieve these by encouraging HEIs to assess and rate their performances against a set of established criteria. ${ }^{61,62}$ This indicates that based on the development and context of higher education in Africa the AU and AAU prefer rating to ranking. Hence, regardless of its feasibility and acceptability, AQRM could also subtly serve as a continental replacement for the global university ranking mechanisms.

HAQAA - one of the PAQAF's initiatives - aims to "contribute to and support the harmonisation of higher education programmes and the creation of a distinctive, attractive and globally competitive African higher education space, through enhanced intra-African collaboration." ${ }^{63}$ Its major activities include developing the African Standards and Guidelines for Quality Assurance in higher education (ASG-QA). The ASG-QA, which is mainly adapted from the Standards and Guidelines for Quality Assurance in the European Higher Education Area (ESG), provides an overarching framework for quality assurance. It complements the $\mathrm{AQRM}$ in enhancing the institutional culture of quality in African HEIs.

The AUC is also developing the African Continental Qualification Framework and planning to establish an African Credit Accumulation and Transfer System, a Continental QA and Accreditation Agency, a Continental Register for QA agencies and quality assured HEIs which are similar to the European Credit Accumulation and Transfer System (ECTS), European Quality Assurance Agency (EQAA) and European Quality Assurance Register for Higher Education (EQAR) respectively. These and the above discussions clearly indicate Africa's over dependence on harmonisation initiatives and strategies that are developed elsewhere.

\section{EU's influence on the higher education reform in Africa}

Africa wants to get out of the bottom level of global knowledge production, research and innovation and aspires to become one of the global

${ }^{60}$ Mohamedbhai, "Towards an African higher education", 6.

${ }^{61}$ Juma Shabani, Peter Okebukola, and Olusola Oyewole, "Regionalization of Quality Assurance in Africa," in Regionalization of African Higher Education, ed. Jane Knight and Emnet. T. Woldegiorgis (Rotterdam: Sense Publisher, 2017), 93-112. https://doi.org/ 10.1007/978-94-6300-956-0_6.

${ }^{62}$ Lazarus Nabaho and Wilberforce Turyasingura, "An Exploration of the 'African (Union Commission's) Perspective' of Quality and Quality Assurance in Higher Education: Latent Voices in the African Quality Rating Mechanism (AQRM)," Tuning Journal of Higher Education 6, no. 2 (2019): 73-95, doi: http://dx.doi.org/10.18543/tjhe-6(2)-2019pp73-95.

${ }^{63}$ European Commission, "Harmonisation of higher education in Africa," 2015, https:// www.africa-eu-partnership.org/sites/default/files/harmonisation_factsheet.pdf. 
competitive forces in higher education. This requires significant reform at different levels, and major stakeholders and continental policy makers considered the Bologna Process as an ideal strategy for achieving this purpose. This is mainly because first, some of the challenges that Africa is facing are similar to that of Europe. Secondly, the Bologna Process is considered as state of the art in the harmonisation of higher education worldwide. Thirdly, the Bologna Process has been gaining momentum in most African countries ${ }^{64}$ even before the AU has embarked on developing a strategy for harmonising African higher education. From this point of view and theoretically, it can be argued that the 'Bologna-Framed' higher education reform in Africa is a 'voluntary' harmonisation process. However, practically the reform is considerably influenced by the EU. The EU has used different mechanisms to influence and make sure that the higher education reform in Africa adheres to the principles and strategies of its Bologna Process. The following are some of the major mechanisms.

The EU uses the Africa-EU partnership as an overarching strategy to achieve the objectives of the external dimension of the Bologna Process which is a soft strategy that aims to influence the dynamics of higher education beyond Europe. Under this partnership, the EU has provided sizable financial support to a number of higher education strategies and reforms in Africa. These include but are not limited to Tuning Africa, AHERS, PAQAF, and Intra-Africa academic mobility scheme. It ensures that these strategies and reforms are in line with the Bologna Process through its 'technical support'. The EU 'technical support' involves, among others, sharing experiences of reform processes through arranging exposure visit to different groups involved in the reform, and providing consultancy services through European companies and institutions that promote the notions and values of the Bologna Process in the development and implementation of harmonisation projects.

The other mechanism that the EU uses to influence higher education reform in Africa is through including elements of the Bologna Process in its funding opportunities for African HEIs. For example, the Intra-Africa Academic Mobility Scheme requires applicant and partner institutions to include strategies for modernisation and internationalisation, mechanisms for comparability and complementarity of curricula and recognition of study period and qualifications obtained abroad. It also influences the reform through supporting the higher education cooperation between the

${ }^{64}$ Hocine Khelfaoui, "The Bologna Process in Africa: Globalization or Return to 'Colonial Situation'?," Journal of Higher Education in Africa 7 no. 1/2 (2009): 23-40. 
Bologna member countries and some of the former European colonies that requires the latter to reform its higher education through persuasion or coercion.

One of EU's indirect mechanisms for influencing the higher education reform in Africa is by promoting values and impacts of the Bologna Process through promoting Erasmus Mundus Students and Alumni AssociationAfrican Chapter, using its different agencies (e.g. the European Association for Quality Assurance in Higher Education and the Association of European Universities) and using platforms and initiatives organized and developed by international organisations (e.g. UNESCO and the World Bank). ${ }^{65}$

Here, it is important to highlight why the EU wants to influence higher education reform in Africa and why some African countries and scholars are cautious of the EU's interest to support harmonisation initiatives in Africa. Europe had many African colonies which were considered as a source of production of raw materials by their colonial masters. Many years after independence, the global north including Europe still consider Africa as the dominant source of raw materials and major consumers of manufactured products. ${ }^{66}$ In relation to this, Europe wants to strengthen its strategic relationship with Africa to ensure and sustain its political and economic interests. Accordingly, it came up with the Africa-EU partnership which includes investing in people - education, science, technology and skills development as one of the priority areas in which most of the higher education harmonisation initiatives are included. Education significantly influences our attitudes, values, norms, opinions and perspectives. It is a gateway to achieve one's (individual, national, regional and continental) interest both directly and indirectly. Hence, it is not surprising to see education, research and innovation as one of the major components of the Pan-African Programme which is one of the main EU's financial instruments for the implementation of the joint Africa-EU partnership.

Africa was intentionally exploited and underdeveloped by European colonial masters ${ }^{67}$ (Walter, 1973) which should be held accountable for the present economic and political situation of the continent. It was unarguable

${ }^{65}$ Foteini Asderaki, "Researching the European Higher Education Area External Effectiveness: Regime Complexity and Interplay," European Journal of Higher Education 9, no. 1 (2019): 40-57.

${ }^{66}$ Stephen Ocheni, Basil C. Nwankwo, "Analysis of colonialism and its impact in Africa,” Cross-Cultural Communication 8, no.3 (2012): 46-54. http://dx.doi.org/10.3968/j. ccc.1923670020120803.1189.

67 Walter Rodney, "How Europe underdeveloped Africa," (Bogle-L'Ouverture Publications, London and Tanzanian Publishing House, Dare Salaam, 1973). 
that education was one of the main instruments used by European colonizers to create a continent that serves European interest by disentangling Africans from their identities, values, norms and traditions. Because of their past experience, despite positive elements of continental level partnership in education, Africans have been skeptical of EU's partnership and involvement in education development including its technical and financial support to the harmonisation initiatives.

\section{Factors affecting the implementation and institutionalisation of harmonisation of higher education in Africa}

The development and implementation of strategies for harmonisation of higher education at supranational and international level requires the political commitment of different countries because harmonisation of higher education is similar to higher education regionalism which is "a political project of region creation involving at least some state authority (national, supranational, international), who in turn designates and delineates the world's geographical region to which such activities extend, in the higher education policy sector." ${ }^{68}$ EU's financial support and its nations' political commitment and HEIs' positive response to proposed reforms and changes in structures (e.g. degree structures) are some of the enabling environments for the much acclaimed harmonisation of higher education in Europe. This clearly indicates that developing or adapting different reform strategies, initiatives and tools are necessary but not sufficient conditions for effective implementation and institutionalisation of harmonisation of higher education which also requires national and continental concerted effort, funding and political commitment.

Some of the harmonisation initiatives (e.g. the joint curriculum development and the continental quality rating mechanism) to a certain extent take into consideration the continental and regional educational interests and focus areas. Although such initiatives have been positively received by continental, regional and national educational actors, aligning the initiatives and strategies to the institutional and national context is a major challenge. In Africa, the political commitment of most countries is also one of the biggest challenges and threats to the implementation and sustainability of the strategies for harmonisation of higher education in

${ }^{68}$ Meng-Hsuan Chou and Pauline Ravinet, "The Rise of 'Higher Education Regionalism': An Agenda for Higher Education Research," in Handbook of Higher Education Policy and Governance, ed. Jeroen Huisman, et al. (Basingstoke: Palgrave, 2015), 361-378. 
Africa. Although most African countries are engaged in the development and adaptation of continental harmonisation strategies, their commitment to the implementation of harmonisation strategies is questionable. For example, as discussed earlier, the Arusha Convention was able to attract about 20 countries within three decades. The revised Convention (the Addis Convention) was endorsed in 2014 and entered into force on 15 December 2019. However, despite continual reminders by UNESCO and the Association of African Universities (AAU), as of October 2020 only 12 countries have ratified the Convention. This clearly shows the lack of most countries' political commitment to the continental higher education reforms.

"It is not surprising that territories and countries that have had colonial ties to Member States of the European Union are offered better treatment than those territories and countries that have not had such ties." ${ }^{69}$ While this may be good for different reasons, it is also important to note that there are Africans who do not see this positively because of their experience of colonialism. The colonial education system in Africa, which was based on the needs of European, subjugated indigenous language and culture and perpetuated dependency. ${ }^{70}$ The vestiges of the colonial footprint on African education are still evident and enduring. Accordingly, many scholars have promoted decolonisation of the education system in Africa. ${ }^{71,72,73}$ Because of this, there are Africans who are critical of Europe's involvement in Africa's education system regardless of its current interest to support harmonisation initiatives. There are also Africans who consider the involvement of Europe in African education through partnership and cooperation as a strategy for facilitating continuation of Western exploitation. This also affects effective implementation of EU driven harmonisation initiatives in Africa.

African countries have widely varying higher education systems and this is a challenge for harmonisation by itself. This is also partly a reason for

${ }^{69}$ Morten Broberg, "The EU's legal ties with its former colonies: When old love never dies”. DIIS Working Paper, No. 2011:01, Danish Institute for International Studies, 2011. https://www.econstor.eu/bitstream/10419/44696/1/64506016X.pdf.

${ }^{70}$ Mamadou Gaye, "Western influences and activities in Africa," Journal of Third World Studies 15, no. 1 (1998): 65-78.

${ }^{71}$ Foluke Adebisi, "Decolonising education in Africa: Implementing the right to education by re-appropriating culture and indigeneity," Northern Ireland Legal Quarterly, 67, no.4 (2016): 433-451. https://doi.org/10.53386/nilq.v67i4.129.

${ }^{72}$ Ruth M. Mampane, Margaret F. Omidire, and Folake Ruth Aluko, "Decolonising higher education in Africa: Arriving at a glocal solution," South African Journal of Education, 38, no.4 (2018): 1-9. https://doi.org/10.15700/saje.v38n4a1636.

${ }^{73}$ Dennis Ocholla, "Decolonizing higher education in Africa: Implications and possibilities for university libraries,". International Insights, 81, no.6 (2020). 
some African countries' preference to align their higher education with the higher education system of their former colonies of European countries because of strong relations, strategic alliances and language. Moreover, some countries are more interested and committed to sub-continental than continental level harmonisation activities which are also drawn from the European experiences. This is mainly because, first, some of the continental level harmonisation strategies and tools have been developed after the countries have engaged in the sub-continental level harmonisation process. Second, those already involved in different sub-continental level harmonisation initiatives do not see strong added value that necessitate active engagement in the continental level harmonisation, and some of them even consider their continental level participation as duplication of efforts. This clearly indicates that as much as it is an opportunity, the on-going national and sub-continental level harmonisation is a challenge for the continental level harmonisation process. Moreover, the fragmented sub-continental level harmonisation initiatives promote South-North than South-South cooperation and harmonisation and "present a significant risk of perpetuating dependency on the old colonial legacies"

AU's commitment to harmonise African higher education is clear and important but its financial support to the harmonisation frameworks, strategies, initiatives and tools are not strong and mostly supported by its European counterpart. Most African countries seem to be also interested in the harmonisation strategies and initiatives so long as it has no significant financial implication. Yet, it is clear that harmonisation and its different activities are not that cheap, and this could be considered as a burden for the already underfunded higher education sector.

HEIs are major stakeholders that are responsible for implementing and benefiting from the outcomes of harmonisation of higher education. However, unlike in Europe, many HEIs in Africa are not well informed and actively engaged in the development and adaptation of different continental strategies for harmonisation of higher education. This potentially results in institutional resistance to the implementation of proposed changes and reforms related to harmonisation of higher education. The absence of a strong and committed body that feeds the continental harmonisation process based on empirical data is also another challenge for effectively implementing and fine-tuning the harmonisation process.

${ }^{74}$ Ement T. Woldegiorgis, Regionalization of Higher Education in Africa: The Operationalization of the African Union Higher Education Harmonization Strategy (Berline: Lit Verlag, 2017). 
Some studies promote the importance of drawing valuable lessons from the Bologna Process ${ }^{75,76}$ because of some similar challenges that both Africa and Europe have faced and the majority of African countries are former colonies of European countries that still have close collaboration in higher education. Other studies consider the Bologna Process as "a new paradigm of domination carried by the agents of globalization", 77 "a tool that European countries used for their hegemonic project on Africa's higher education", ${ }^{78}$ "a panacea to African higher education" ${ }^{79}$ a strategy that aims "to raise the flow of (good) non-European students into European universities", ${ }^{80}$ and a reform which "does not solve the challenges and problems of the African higher education" ${ }^{81}$ These kinds of perceptions and understandings are among the potential factors that affect effective implementation and institutionalisation of the "Bologna-Framed" harmonisation of higher education in Africa.

Continental, national and institutional education policies, strategies, initiatives and reforms are often informed and influenced by different global actors. Therefore, it is important and strategic to take good lessons from different experiences. However, the attempt to influence the African higher education systems to fit into the strategies and initiatives formulated and developed elsewhere in different contexts, instead of moulding the strategies and initiatives to align with local higher education systems has been a challenge for the implementation of harmonisation strategies and initiatives.

\section{Conclusion}

The efforts made by the AU to deal with this priority are creditable. It is crystal clear that harmonisation of higher education in Africa is shaped by the

${ }^{75}$ Mohamedbhai, "Towards an African higher education”, 38.

${ }^{76}$ Damtew Teferra, The Bologna Process: The Experience and Challenges for Africa," in The Bologna Process and the Shaping of the Future Knowledge Societies: Conference Report from the Third Conference on Knowledge and Politics, ed. Tor Halvorsen and Attle Nyhagen (Bergen: University of Bergen, 2005), 287-293.

77 Khelfaoui. "The Bologna Process in Africa", 24.

${ }^{78}$ Jean-Emile Charlier and Sarah Croché, "The Bologna Process: A tool for Europe's Hegemonic Project on Africa". Power and Education 3, no.3 (2011): 304-316. https://doi. org/10.2304/power.2011.3.3.304.

79 Zmas, "Global impacts of the Bologna Process", 12.

${ }^{80}$ Charlier and Croche, "Can the Bologna Process", 40.

${ }^{81}$ Sintayehu. K Alemu, "African Higher Education and the Bologna Process," European Journal of Higher Education 9 no. 1 (2019): 118-132. https://doi.org/10.1080/21568235.2018. 1561313. 
Bologna Process and fundamentally influenced by the EU which is AU's prime political partner in the development of higher education and the principal financer and 'technical supporter' of most of the harmonisation projects in the continent. Africa welcomed the Bologna Process without establishing strong and genuine cooperation among its HEIs and ensuring nations' political and financial commitment to the promotion and implementation of national and continental higher education reforms. These factors led to frivolous adaptation and attempts to influence the African higher education systems to fit into the strategies and initiatives formulated and developed elsewhere in different contexts. This in turn has led to fragmented, inconsistent and ineffective implementation of the "Bologna-Framed" harmonisation of higher education in Africa. Although it is early to generalize, current trends and practice indicate that it is very likely that Africa and its HEIs will continue struggling to institutionalise and ensure the sustainability of the "Bologna-Framed" harmonisation process for a foreseeable future.

Therefore, to turn these around, Africa needs genuine and strong "conainsation" which is the process of continentalisation, nationalisation and institutionalisation of theories, ideas, notions, policies, strategies, approaches, initiatives, practices, etc. by putting the intended context at the center of the process. "Conainsation" thoroughly defies one-size-fits-all approach which often disregards contexts, and paves the way for coerced implementation and "self-imposed colonisation" which is subscribing to external prescriptions through coercion or ignorance or without critical inquiry to its ultimate relevance to local (continental, national and institutional) context. Africa also needs to think about developing innovative strategies for harmonisation of higher education which is mainly based on its identified challenges and problems and actual needs, and clear ultimate goals set to be achieved.

\section{Bibliography}

Adamu, Abebaw Yirga. "Internationalization of higher education in Africa: Introducing credit accumulation and transfer system." International Journal of Public Policy, 8, no. 4/5/6 (2012): 199-213.

Adebisi, Foluke. "Decolonising education in Africa: Implementing the right to education by re-appropriating culture and indigeneity." Northern Ireland Legal Quarterly, 67, no. 4 (2016): 433-451.

African Union Commission and European Commission. "Preface." In Tuning and harmonisation of higher education: The African experience, edited by Charles Awono Onana, et al. 9-10. Bilabo: University of Deusto, 2014.

African Union. "Second Decade of Education for Africa (2006-2015): Plan of Action," 2006, http://www.unesco.org/new/fileadmin/MULTIMEDIA/FIELD/ 


\section{Dakar/pdf/AU\%20SECOND\%20DECADE\%20ON\%20EDUCTAION\%20} 2006-2015.pdf

African Union. Harmonization of higher education programmes in Africa: A strategy for the African Union. Addis Ababa: African union, 2007.

African Union. "African quality rating mechanism (AQRM) survey questionnaire.

Revised version," 2013. https://au.int/sites/default/files/newsevents/working documents/27609-wd-aqrm_q_english_august_2013.pdf

African Union. "First progress report of the chairperson of the commission on academic mobility scheme in Africa," 2018. https://au.int/sites/default/files/ documents/34072-doc-auc.report.academic.mobility. prc_.29.03.pdf

Alemu, Sintayehu Kassaye. "African higher education and the Bologna Process." European Journal of Higher Education, 9 no. 1 (2019): 118-132.

Asderaki, Foteini. "Researching the European Higher Education Area external effectiveness: Regime complexity and interplay." European Journal of Higher Education, 9, no. 1 (2019): 40-57.

Association for the Development of Education in Africa. "Policy brief: Harmonization of higher education in Africa or why we need to hang in there together...." 2015, http://www.adeanet.org/en/system/files/policy_brief_harmonization_en.pdf

Bergen Communiqué. "European Higher Education Area - Achieving the goals". Communiqué of the Conference of European Ministers Responsible for Higher Education. Bergen, 19-20 May 2005. http://ehea.info/media.ehea.info/file/ 20050412-13_Mondorf/67/6/BFUG5_8_Draft_579676.pdf

Bologna Declaration. "Joint declaration of the European Ministers of Education," 1999, https://www.eurashe.eu/library/bologna_1999_bologna-declaration-pdf/

Brandle, Tobias. "Only a matter of education policy ideals? German professors' perception of the Bologna Process." Higher Education Quarterly, 70, no. 4 (2016): 354-383.

Broberg, Morten. “The EU's legal ties with its former colonies: When old love never dies". DIIS Working Paper, No. 2011:01, Danish Institute for International Studies, 2011. https://www.econstor.eu/bitstream/10419/44696/1/64506016X. pdf.

Carnoy, Martin. "Globalisation, educational trends and the open society". Open Society Institute, Education Conference - Education and open society: A critical lookatnew perspectivesanddemands, 2005,https://www .opensocietyfoundations. org/uploads/7 fab0f35-4f84-4ed7-82d6-ee2346b7c142/ carnoy_english.pdf

Chao, Roger. J. "Reflections on the Bologna Process: the making of an Asia Pacific Higher Education Area." European Journal of Higher Education, 1, no. 2-3 (2011): 102-118.

Charlier, Jean-Emile and Sarah Croche. "Can the Bologna Process make the move faster towards the development of an international space for higher education where Africa would find its place?" Journal of Higher Education in Africa, 7, no. $1 \& 2$ (2009): 39-59.

Charlier, Jean-Emile and Sarah. Croché. "The Bologna Process: A tool for Europe's hegemonic project on Africa". Power and Education, 3, no.3 (2011): 304-316. 
Chou, Meng-Hsuan and Pauline Ravinet. “The rise of 'higher education regionalism': An agenda for higher education research." In Handbook of higher education policy and governance, edited by Jeroen Huisman, Harry De Boer, David D. Dill, and Manuel Souto-Otero, 361-378. Basingstoke: Palgrave, 2015.

Crosier, David and Teodora Parveva. The Bologna Process: Its impact on higher education development in Europe and beyond. Paris: UNESCO, 2013.

European Commission. "Harmonisation of higher education in Africa," 2015, https:// www .africa-eu-partnership.org/sites/default/files/harmonisation_factsheet.pdf

European Commission. "Towards the European Higher Education Area by 2025," 2018, https://ec.europa.eu/commission/news/towards-european-education-area2025-2018-may-22_en

European Commission/EACEA/Eurydice. "The European Higher Education Area in 2018: Bologna Process implementation report". Luxembourg: Publications Office of the European Union, 2018.

Garwe, E. Chiyevo and Lovemore Gwati. "The role of international and regional quality assurance bodies." Higher Education Research, 3, no. 1 (2018): 15-22.

Gaye, Mamadou. "Western influences and activities in Africa." Journal of Third World Studies, 15, no. 1 (1998): 65-78.

Hahn, Karola and Damitew Teferra. "Tuning as instrument of systematic higher education reform and quality enhancement: The African experience." Tuning Journal for Higher education, 1, no. 1 (2013): 127-163.

Hoosen, Sarah, Neil Butcher, and Betarice K. Njenga. "Harmonisation of higher education programmes: A strategy for the African Union." African Integration and Development Review, 3, no. 1 (2009): 1-36.

Kehm, Barbara M. "The future of the Bologna Process -The Bologna Process of the future." European Journal of Education, 45, no. 4 (2010): 529-534.

Khelfaoui, Hocine. "The Bologna Process in Africa: Globalization or return to 'colonial situation'?" Journal of Higher Education in Africa, 7 no. 1/2 (2009): 23-40.

Klemenčič, Manja. "20 Years of the Bologna Process in a Global Setting: The external dimension of the Bologna Process revisited." European Journal of Higher Education, 9, no.1 (2019): 2-6.

Knight, Jane. "A model for the regionalization of higher education: The role and contribution of tuning." Tuning Journal for Higher education, 1, no. 1 (2013): 105-125.

London Communiqué. "European higher education in a global setting: A strategy for the external dimension of the Bologna Process," London, 17-18 May 2007. http://www.ehea.info/media.ehea.info/file/EHEA_in_a_Global_Context/24/2/ Strategy_plus_possible_actions_597242.pdf

Lunt, Ingrid. "The implementation of the BP for the development of a European qualification in psychology." European Psychologist, 10, no. 2 (2005): 86-92.

Mampane, Ruth M., Margaret F. Omidire, and Folake Ruth Aluko. "Decolonising higher education in Africa: Arriving at a glocal solution." South African Journal of Education, 38, no.4 (2018): 1-9. 
Matthews, David. "Bologna Process still 'treading water', say critics”. The World University Ranking, May 29, 2018, https://www timeshighereducation.com/ news/bologna-process-still-treading-water-say-critics

Mitchell, Douglas E. and Selin Yildiz Nielsen. "Internationalisation and globalisation in higher education." In Globalisation, Education and Management, edited by Hector Cuadra-Montiel, 3-22. London: IntechOpen, 2012.

Mohamedbhai, Goolam. "Towards an African higher education and research space (AHERS): Summary report," 2013, http://www .adeanet.org/en/system/files/ resources/ahers_summary_report.pdf

Moscovitz, Hannah and Hila Zahavi. "The Bologna Process as a foreign policy endeavour: Motivations and reactions to the externalisation of European higher education.” European Journal of Higher Education, 9, no. 1 (2019): 7-22.

Nabaho, Lazarus and Wilberforce Turyasingura. "An exploration of the 'African (Union Commission's) perspective' of quality and quality assurance in higher education: Latent voices in the African Quality Rating Mechanism (AQRM)." Tuning Journal for Higher Education, 6, no.2 (2019): 73-95.

Ocheni, Stephen, Basil C. Nwankwo. Analysis of Colonialism and Its Impact in Africa. Cross-Cultural Communication, 8 no. 3 (2012): 46-54.

Ocholla, Dennis. "Decolonizing higher education in Africa: Implications and possibilities for university libraries." International Insights, 81, no.6 (2020).

OECD. “Executive Summary.” In Higher Education to 2030, Volume 2, Globalisation, 13-16. Paris: OECD, 2009. https://doi.org/10.1787/9789264075375-en

Oyewole, Olusola. "African harmonisation: An academic process for a political end?" Chronicle of African Higher Education, 2013, http://www.inhea.org/wpcontent/uploads/2016/02/Oyewole-Harmonisation.pdf

Pechar, Hans. "The decline of an academic oligarchy: The Bologna Process and 'Humboldt's last warriors." In European higher education at the crossroads: Between the Bologna Process and national reforms, edited by Adrian Curaj, Peter Scott, Lazar Vlasceanu, and Lesley Wilson, 613-630. Dordrecht: Springer, 2012.

Rodney, Walter. How Europe underdeveloped Africa. London: Bogle-L'Ouverture Publications and Dare Salaam: Tanzanian Publishing House, 1973.

Shabani, Juma, Peter Okebukola, Olusola Oyewole. "Quality assurance in Africa: Towards a continental higher education and research space." International Journal of African Higher Education, 1, no. 1 (2014): 139-171.

Shabani, Juma, Peter. Okebukola, and Olusola Oyewole. "Regionalization of quality assurance in Africa." In Regionalization of African higher education, edited by Jane Knight and Emnet. T. Woldegiorgis, 93-112. Rotterdam: Sense Publisher, 2017.

Sorbonne Declaration. "Joint declaration on harmonisation of the architecture of the European higher education system," 1998, http://www.ehea.info/media.ehea. info/file/1998_Sorbonne/61/2/1998_Sorbonne_Declaration_English_552612. pdf

Tauch, Christian. "The Bologna Process: State of implementation and external dimension." In Opening up to the wider world: The external dimension of the 
Bologna Process, edited by Franziska Muche, 23-30. Bonn: Lemmens Verlagsand Mediengesellschaft mbH, 2005.

Teferra, Damtew. "The Bologna Process: The experience and challenges for Africa." In The Bologna Process and the shaping of the future knowledge societies: Conference Report from the Third Conference on Knowledge and Politics, the University of Bergen, May 18-20th 2005, edited by Tor Halvorsen and Attle Nyhagen, 287-293. Bergen: University of Bergen, 2005.

Teferra, Damtew. "The international dimension of higher education in Africa: Status, challenges, and prospects." In Higher education in Africa: The international dimension, edited by Damtew Teferra and Jane Knight, 44-79. Accra: Association of African University, 2008.

UNESCO. "Higher education in a globalized society: UNESCO Education Position Paper." Paris: UNESCO, 2004.

UNESCO. "The new dynamics of higher education and research for societal change and development". World Conference on Higher Education. Communiqué. July 5-8, 2009, Paris: UNESCO.

UNESCO. "Revised convention on the recognition of studies, certificates, diplomas, degrees and other academic qualifications in higher education in African States." 12 December 2014, Addis Ababa, 2014.

UNESCO. "Evaluation of UNESCO's regional conventions on the recognition of qualifications in higher education.” Paris: UNESCO, 2016.

Westerheijden, F. Don, Eric Beerkens, Leon Cremonini, Jeroen Huisman, Barbara Kehm, Aleksandra Kovac, Predrag Lazetic, et al. The First Decade of Working on the European Higher Education Area: The Bologna Process Independent Assessment: Executive Summary, Overview and Conclusions. Ghent: University of Ghent, 2010.

Woldegiorgis, Emnet T. "Conceptualizing harmonization of higher education systems: The application of regional integration theories on higher education studies." Higher Education Studies, 3 no. 2 (2013): 12-23.

Woldegiorgis, Ement T. Regionalization of higher education in Africa: The operationalization of the African Union higher education harmonization strategy. Berline: Lit Verlag, 2017.

Woldegiorgis, Emnet T., Petronella Jonck, and Anne Goujon. "Regional higher education reform initiatives in Africa: A comparative analysis with the Bologna Process." International Journal of Higher Education, 4, no.1 (2015): 241-253.

Woldegiyorgis, Ayenachew. A. "Harmonisation of higher education in Africa and Europe: Policy convergence at supranational level." Tuning Journal for Higher Education, 5 no. 2 (2018): 133-157.

Zgaga, Pavel. Looking out: The Bologna Process in a global setting. On the "External Dimension" of the Bologna Process. Oslo: Norwegian Ministry of Education and Research, 2006.

Zmas, Aristotelis. 2015. "Global impacts of the Bologna Process: International perspectives, local particularities." Compare: A Journal of Comparative and International Education, 45, no. 5 (2015): 727-747. 


\section{About the author}

ABEBAW YIRGA ADAMU (abebawy2001@gmail.com; abebaw.yirga@aau.edu. et) is an associate professor of education at Addis Ababa University. He holds $\mathrm{PhD}$ in Education and Society from the University of Tampere, Finland; MA in Lifelong Learning Policy and Management from the University of Aarhus, Denmark and University of Deusto, Spain (Erasmus Mundus Joint Master Degree); MEd in Multicultural and Multilingual Education from Addis Ababa University, Ethiopia. He was the Director of Ethiopian Institute for Higher Education, Addis Ababa University and the Director of Quality Assurance, Ethiopian Institute of Architecture, Building Construction and City Development, Addis Ababa University. He was NAFSA Global Dialogue Fellow (2019-2020), and UASP-Research Management and Leadership Fellow (2019). He is member of the Comparative and International Education Society, Ethio-Finland Alumni Association, Erasmus Mundus Student and Alumni Association, African Students Alumni Forum, and Advisory Board Member of the Ethiopian Journal of Social Sciences. His research interest includes higher education (policy, diversity, quality, internationalisation, harmonisation, and leadership) and lifelong learning policy and management. 


\title{
Harmonisation of higher education in Africa: 20 years after the Bologna Process
}

\author{
Abebaw Yirga Adamu \\ doi: http://dx.doi.org/10.18543/tjhe-9(1)-2021pp103-126
}

\section{Copyright}

Copyright for this article is retained by the Publisher. It is an Open Access material that is free for full online access, download, storage, distribution, and or reuse in any medium only for noncommercial purposes and in compliance with any applicable copyright legislation, without prior permission from the Publisher or the author(s). In any case, proper acknowledgement of the original publication source must be made and any changes to the original work must be indicated clearly and in a manner that does not suggest the author's and or Publisher's endorsement whatsoever. Any other use of its content in any medium or format, now known or developed in the future, requires prior written permission of the copyright holder. 